\title{
Losing the Product in the Process
}

Lawrence Baines, Coleen Baines, Gregory Kent Stanley, and Anthony Kunkel

F

ew researchers would dare dispute that the process movement has done wonders to improve the teaching of writing. Emig's The Composing Processes of Twelfth Graders and other publications of the late 1960s and early 1970s made the point that a strictly grammatical approach to writing did not reflect the way that students actually wrote. In 1973 the N ational Writing Project was established to help promulgate the concept that writing might not necessarily follow the circumscribed steps suggested in the lessons available in textbooks, many of which focused upon intricacies of outlining,

grammar, and spelling. $L$ ater, $F$ lower and $\mathrm{H}$ ayes contributed some handy flowcharts that seemed to map out rather neatly the cognitive processes associated with the writing process. At the end of the millennium, "the writing process" has become so accepted as the paradigm for composition that even Warriner's now devotes huge sections of its erstwhile grammatical textbook to "the process."

Still, the extent to which teaching writing as a process affects student achievement and attitudes is somewhat uncertain. Despite over two million teacher graduates from the $\mathrm{N}$ ational Writing Project alone (not including graduates of the $\mathrm{N}$ ew J ersey Writing Project, B readloaf, or any of the other myriad regional and university sponsored sites), the latest $\mathrm{N}$ ational Assessment of $\mathrm{E}$ ducational Progress (N AE P) writing results reveal that the overall writing performance of students has stagnated since the inception of the NAEP assessment of writing some fourteen years ago. M oreover, the data also indicate that students' perceptions of writing haven't changed much either. If teaching writing as a process has had such a tremendous effect on the attitudes and achievement of students, why isn't the evidence on its behalf more convincing?

\section{Three Popular Ways of Teaching "The Process" in Secondary English Classrooms}

Most of the time, creating a piece of interesting writing is difficult enough. Trying to convince a group of adolescents and young adults to crank out substantive papers on demand within the confines of the standard fifty-five minute class period in a room packed with their hormone-happy peers requires both extensive preparation and savvy classroom management skills. We want to emphasize that we respect and admire the incredible work that many of the teachers of writing we observed routinely perform.

Over the past six years, the four of us have observed over three hundred secondary (grades 6-12) teachers of $E$ nglish in the act of teaching writing. While some of the teachers we observed were wonderfully effective and many were quite competent, when we recently compared our observation notes, we discovered that "the process approach to writing" varied from classroom to classroom. We found three basic variations on the process approach that seemed to be very popular among writing teachers, and while these three approaches are certainly not inclusive of the diverse ways in which 
we witnessed writing being taught in secondary schools, they are the three methods we observed again and again. We characterize these three approaches as follows:

1. The "classic" process approach

2. The "antigrammarian" approach

3. The "five paragraph" approach

Each of the scenarios below is entirely fictional, though each is a composite portrait of actual occurrences during our observations.

\section{The "Classic" Process Classroom}

Armed with notes from college and several copies of books about process writing, Mrs. $\mathrm{K}$ lays out plans for an essay assignment. First, students brainstorm events in their lives that they feel are memorable, then they select one specific event about which they would like to write. N ext, the students begin to write down words, fragments, or memories associated with the event. They then group their thoughts into clusters and attempt to order them in preparation for the writing of their essays. This done, students have an outline of sorts to draw from, and they are ready to start writing a rough draft.

"Avoid revision now," Mrs. K suggests. "We'll get to that later."

Quinn raises his hand. "Can't I just write it? I know what I want to write about. D o I have to really go through all this mess?"

The teacher smiles knowingly and explains that by following the steps of the process, Quinn will eventually write a superior essay. The student acquiesces and begins to circle some ideas from those he has written down. Once Q uinn shows M rs. $\mathrm{K}$ his cluster, he is allowed to draft.

From the minute he starts writing, Quinn scribbles with abandon, stopping occasionally to revise as he writes. When she spots this, M rs. K advises, "Quinn, don't break your rhythm. Keep writing."

M rs. K wants her students to be able to organize and format a good essay, but perhaps more importantly, she wants the students to come to enjoy writing, to come to savor the act of reaching within themselves to learn the beauty of their own voices. As M rs. K glances around the room, she notices that some students are staring out the window, some are writing furiously, while others are moving their lips as if reading, struggling over the selection of a particular word, perhaps. The most enthusiastic writers, such as Quinn, have completely abandoned their clusters and are writing away. Others, who had welcomed the structure provided within the prewriting activity, plod away more methodically, paying close attention to their organization and putting little focus on the content of their product.

At the beginning of class the next day, $\mathrm{Mrs}$. $\mathrm{K}$ asks students to get into groups. "G et with your partners and have them read what you wrote yesterday. If you are editing someone else's paper, give the students some explicit suggestions. D on't say anything mean that might hurt someone's feelings, but try to be honest." Q uinn trades his essay with Sophia, who giggles as she reads. "Oh my God, did this really happen?" Sophia asks. After Quinn tells her about the inspiration for his story, he tells Sophia, "You know, your paper is just great. You've got fantastic handwriting, too."

"Should I change the ending? It seems kind of too sad," Sophia says.

"No, it's perfect just the way it is," says Quinn. "By the way, Bill told me that he saw you at the mall the other day and that ..."

Quinn and Sophia's conversation turns more personal and animated as other students complete their peer editing sessions. After a few more minutes, $\mathrm{M} \mathrm{rs.} \mathrm{K}$ asks students to spend the remainder of class revising their papers. "Tomorrow, I want you to turn in the cluster, your rough draft with the comments of your peer editor, and the final paper."

"W hat if your peer didn't give you any suggestions?" asks Sophia. M rs. K shakes her head.

"Surely, Q uinn can help you with something."

Quinn thinks, then says, "You need a title." Sophia looks at her paper and smiles. "I t should be something catchy."

M rs. K and Sophia laugh. After M rs. K walks away, Quinn begins crossing out words on his paper.

"W hat are you doing?" asks Sophia.

"I'm making my rough draft. M rs. $\mathrm{K}$ takes off ten points if you don't include the rough draft. I just cross out some words, then recopy it on another sheet of paper."

Although Mrs. K takes the papers home with the intention of grading them, she usually doesn't finish with them until the next week. Because she doesn't like to "cover students' papers in 
red ink," she tries to be upbeat and positive about students' writing. She mostly gives As to those who turn something in and Bs to those who don't write much or who fail to turn in the cluster or rough draft. The only students who get Cs, Ds, or Fs are those who refuse to write anything.

\section{The "Antigrammarian" Approach}

"D on't worry about grammar," announces M s. M before giving the day's composition assignment. "I won't count off for spelling or punctuation, either. I just want you to write."

"What are we writing about?" asks J amal.

"Whatever you want to write about," replies M s. M with unbridled enthusiasm. "And spelling, grammar, and punctuation don't matter."

"Just tell a story?" asks Jamal.

"Just write whatever you feel like writingyour diary, your feelings about the death penalty, what you did this weekend, how you feel right now at this very moment." for spelling?"

"So, anything?" asks Jamal. "You countin' off

"Just write, Jamal. What matters is what you have to say, not silly commas or periods."

After students finish their pieces, they peer edit. Ms. M sometimes records the grade the peers give and averages it with her own assessment. Almost everyone who turns in a paper gets an $A$ on writing assignments, though grades are more widely distributed on tests over literature and worksheets.

Sometimes students read their compositions aloud, and M S. M often posts student work around the room. Ms. M rarely marks on student papers except to pose a question, make a nonjudgmental comment, or commend a particularly expressive passage.

During a poetry unit, she asks students to write an original poem about a person to whom they feel very close.

Jamal writes about his father:

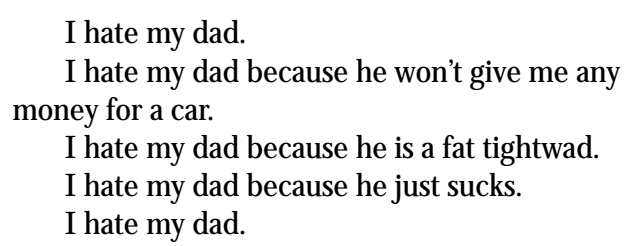

When M s. M hands back Jamal's paper, he comments, "H ey, there's no grade on this!"
M s. M responds, "It is impossible to grade poetry, Jamal. If your poem means something to you, that's what counts."

\section{The "Five Paragraph" Process}

"I don't like to teach the five paragraph essay, but it's what they expect us to teach," says Mr. A, a young man in his second year of teaching. "These students need to know how to write, and in my classes, we practice and practice. To get them ready, I often use a prompt from last year's state writing test. And we go over it and over it until they get it right. The scorers of those tests look to see if students are using the right transitions and if they know how to write a paragraph."

\section{She mostly gives As to those}

\section{who turn something in and Bs}

\section{to those who don't write much}

\author{
or who fail to turn in the \\ cluster or rough draft.
}

Although he teaches English, Mr. A does not like to write but does not necessarily see not being a writer as a detriment to his teaching. "H oward Cosell never boxed, but he was an expert on boxing," he says.

At the beginning of class, Mr. A frequently announces the writing topic for the day. $\mathrm{H}$ e collects student work when the bell rings and runs a thoroughly organized and neat classroom. U sually, students sit silently at their desks while he busily grades the horde of papers that inevitably comes with making frequent writing assignments. When students have questions, they usually walk up to the teacher's desk, where Mr. A cheerfully and patiently answers their questions. If students act sleepy or refuse to complete an assignment, he sends them to the office or gives them detention. The students seem to like M r. A, and he doesn't have to punish students often. 
"Today, we're going to write a comparison/ contrast paper," he says. "I want you to compare two things, maybe soccer and football, and tell how they are alike and how they are different." H e turns on the transparency machine and begins writing with a green felt tip pen. "H ow should I begin such a paper?" he asks.

Julie raises her hand and answers. "Soccer and football are alike and different in many ways."

"Okay, that's good," says M r. A as he writes Julie's sentence on the overhead, turns around to ensure that his writing is legible for students, and begins to field suggestions for the outline of the model paper.

\section{"The Process" and Student Error}

Each of the three popular approaches described above has certain strengths. The "classic" approach allows students to interact with their peers informally and offers a step-by-step procedure for producing a final draft. The "antigrammarian" method might free students who would otherwise feel intimidated or encumbered by the spectres of proper spelling and standard English. The "five paragraph" approach offers a simple structure for students who might flounder without a ready-made format and seems to give both students and teachers a sense of security. Another very appealing, readily apparent aspect of the three approaches is that teachers and students seem quite content within these pleasant and largely stress-free writing environments. Students write and peer edit, teachers distribute generous praise and high grades, and everyone goes home happy.

Regrettably, one consequence of the widespread emergence of "the process" is that the word error has been banished from teachers' vocabularies. Amid our observations of three hundred classrooms, no teacher ever said, "That is wrong," or "This is an error." When we asked teachers what they looked for when they evaluated student writing, we were more likely to get a sermon on the damaging psychological effects of "bleeding red ink all over the page" than a statement regarding attributes of good writing.

Overwhelmingly in our observations, the quality of writing was presented more as a personal choice than a desired goal. That is to say, in conversations with teachers, many claimed that good writing could not be suitably quantified and that bad writing was really not so bad once you understood the plethora of factors behind it-the student's home environment, ethnicity, social life, popularity, absentee record, former teachers.

It is not uncommon for advocates of "the process" to claim that grades are "arbitrary, coercive, and punishing." Furthermore, they contend that "grading writing does not contribute to the learning of writing, and ... [that] they would like to see the practice of grading disappear completely."

U sually, students sit silently

at their desks while he busily

grades the horde of papers that

inevitably comes with making

frequent writing assignments.

Perhaps many who teach "the process" have begun to confuse the act of grading with the gentle art of correcting. While teachers of "the process" often graded papers without correcting them, they seldom corrected papers without grading them. Predictably, the excommunication of error has caused repercussions in many postsecondary institutions. $M$ any adolescents first learn as college freshmen that they aren't flawless masters of the language, when their English professors, usually more concerned with the quality of a piece of writing than the fragile psyche of its author, return the first batch of papers.

\section{The Lonely, Arduous Quest for Quality}

M ost of the teachers we observed taught at least five classes containing a minimum of thirty students each; thus, giving a composition assignment meant that teachers would grade 150 or more papers during off-hours in the evening or early morning. If teachers could quickly read, correct, and evaluate a set of 150 at the blistering pace of five minutes per composition (almost impossible for any composition longer than a paragraph), they would still have to log at least twelve and a half 
hours of solid grading. If teachers do not require proper grammar, then grammar does not have to be graded. There should be little surprise, then, that many teachers of "the process" have heeded researchers' calls for less error correction and fewer evaluative comments. Besides saving time, this method eliminates being the bearer of the bad news that much work still needs to be done.

In analyzing how authors really write (as opposed to how writers of writing books say that writers should write), we eventually come to the conclusion that real writing always begins in intensity or discomfiture and may take highly idiosyncratic forms. E arl Stanley Gardner wrote so much that an editor once joked that he wrote as though his hair were on fire. Rex Stout believed that if the words did not pour forth from his pen in perfect prose, then his story wasn't any good. J. G. Ballard used to write in his bathtub at four o'clock in the morning. John Dewey would often stare out of a window for hours at a time. I mmanuel Kant used to walk the same path around his German village in order to work through ideas in his head. Today, the increasing sophistication of word processing and authoring programs for computers gives writers even more tools from which to choose.

\section{R egrettably, one consequence of}

\section{the widespread emergence of "the}

\section{process" is that the word error has}

\section{been banished from teachers'}

\author{
vocabularies.
}

What is interesting about each of the three major approaches to process writing is that many teachers we observed seemed more dedicated to "the process" than to improving the quality of students' writing. Of course, teachers may not be able to bring in bathtubs, scout out walking trails, or even open the windows of their classrooms (though these ideas might do no harm) in order to get students to write well, but they can at least imbue the teaching of writing with a little intensity, flexibility, and (perhaps most importantly) honesty. Somehow, for many teachers, the process approach to writing has come to be equated with a set of sequential, pseudo-scientific steps, irrespective of how individual students really write or the tangible outcomes of their efforts. The product has become of secondary importance-an absurd victory of form over content.

\section{A Paradigm That Needs Breaking}

In the classrooms we observed, the obsession with process, at times, crowded out the hard, dirty work of learning how to write well. Grammar, spelling, vocabulary, or sentence structure were rarely, if ever, mentioned. Although we are not nostalgic about the painfully dull and irrelevant practice of teaching writing through decontextual ized drill, we feel that many teachers of "the process" have too flippantly rejected the prospect that a student somewhere might eventually need to know the rule of grammar regarding subject and verb agreement. There is nothing heinous about informing individual students where their writing falters from standard E nglish. O nce informed, these students can at least have the option of learning standard English so that they can use it appropriately, should they find themselves in a position where such knowledge may be required-in a job, for example.

So, what can teachers do to improve how writing is taught and learned? F or one thing, they can consider allowing the idea of error back into the classroom. Although a student may experience some unpleasant disequilibrium when an error is identified, the experience is not something from which most students will be unable to recover. While it is commendable to be concerned with students' sensitivities, the self-esteem of most adolescents is a little beyond being manipulated by gold stars or push-button pleasantries, anyway. Rather than post a "No Hunting Allowed!" sign on the door, as K irby, Liner, and Vinz suggest, to dissuade students from making rude remarks about each others' writing, perhaps a teacher could post a "Constructive Comments Welcome!" sign and help students track and analyze their progress towards overcoming their most common mistakes.

Teachers of writing might also loosen up with regard to "the process" that students use to get to the endpoint of a piece of writing. Most worthwhile 
writing begins in the gut or the heart and has little to do with the lockstep allegiance to the simplistic mantra of "brainstorm/draft/revise." E ven most advocates of "the process" acknowledge that students who care about their subject will write more convincingly than students who don't.

\section{What is interesting about each}

$$
\text { of the three major approaches }
$$

to process writing is that many

$$
\begin{aligned}
& \text { teachers we observed seemed } \\
& \text { more dedicated to "the process" }
\end{aligned}
$$

$$
\begin{aligned}
& \text { than to improving the quality } \\
& \text { of students' writing. }
\end{aligned}
$$

F inally, teachers of writing might reconsider their goals for student writing. Which is more important-self-esteem or achievement, standard English or dialect, process or product? In the current educational climate, a teacher acknowledging that one piece of writing might be more lucid, more moving, more eloquent-or dare we say it? - better than another would be tantamount to treason. In the never-ending struggle to preserve self-esteem, nothing can be said that might offend or hurt another's feelings. As a result, "the process" has become so ubiquitous as to mean anything, or perhaps more precisely, it has come to mean almost nothing. Tragically, the art and soul of writing have been lost in the process.

\section{Works Cited}

E mig, J anet. The Composing Processes of Twelfth G raders. U rbana, IL : N CTE , 1971.

F lower, L inda, and J ohn H ayes. "I mages, Plans and Prose." W ritten Communication (Jan. 1984): 120-60.

- - - . "A Cognitive Process Theory of Writing." College Composition and Communication 32 (1981): 365-87.

Kirby, Dan, Tom Liner, and Ruth Vinz. Inside Out. Portsmouth, N H : H eineman-B oynton/C ook, 1988.

Warriner, John. English Composition and Grammar: An Introductory Course. Orlando, FL: H arcourt Brace, 1988.

Lawrence Baines and Coleen Baines teach at Berry College, M ount Berry, Georgia. Gregory Kent StanLEY teaches at Calhoun High School, Calhoun, Georgia. ANTH ONY KUNKEL teaches at Rome H igh School, Rome, Georgia.

\section{Call for Proposals}

Organizers of the Yosemite Conference, to be held October 22-24, 1999, at Yosemite N ational Park, are seeking proposals on any aspect of teaching the E nglish language arts. The theme of the conference is "A Teacher Affects E ternity." Proposals should be sent to Faith Nitschke, '99 Program Chair, 764 E. June L ake L ane, F resno, CA 93720; phone: (559) 434-4402; e-mail: fn017@csufresno.edu. 